\title{
Determinants of the Difference between Actual Cost and Indonesian Case Based Groups (INA-CBGs) Reimbursement for Birth Delivery at Hospitals in Mataram, West Nusa Tenggara
}

\author{
Baiq Holisatul Ismiana'), Didik Tamtomo²), Endang Sutisna Sulaeman²) \\ ${ }^{1)}$ Masters Program in Public Health, Universitas Sebelas Maret \\ 2)Faculty of Medicine, Universitas Sebelas Maret
}

\begin{abstract}
Background: Health is the part of the economic and social development of the state. The application of the BPJS Health national social security system in Indonesia is one of the government's efforts to provide health financing protection for all citizens and prevent catastrophic health expenditures. Hospitals as providers of secondary or tertiary health services often suffer losses because the payment system from BPJS Kesehatan uses a case based payment method or INA-CBGs. This study aimed to examine the factors that influence the difference in rates between INA-CBGs rates and real hospital rates in labor cases.

Subjects and Method: This was an analytic observational study with a cross sectional design. The study was carried out in Mataram and Siti Hajar Mataram Islamic hospitals, Mataram, West Nusa Tenggara, in May 2019. A sample of 200 postpartum women was selected by stratified random sampling. The dependent variable was the difference between real cost and INA-CBGs reimbursement. The independent variables were type of hospital, class of treatment, type of birth delivery, length of stay, and severity disease. The data were collected from medical record and analyzed by a multiple linear regression run on Stata 13 .

Results: Difference between real cost and INA-CBGs tariff of birth delivery reimbursement was negatively affected by type III of class treatment $(\mathrm{b}=-390,725 ; 95 \% \mathrm{CI}=-790,082$ to 8,$631 ; \mathrm{p}=$ $0,055)$, section caesarean ( $b=-1,429,648 ; 95 \% \mathrm{CI}=-1,811,275$ to $-1,048,022 ; \mathrm{p}<0.001)$, length of stay $(b=-211,912 ; C I(95 \%)=-427,786$ to 3,$960 ; p=0.054)$, moderate severity $(b=-114,028 ; 95 \%$ $\mathrm{CIi}=-507,057$ to 279,$000 ; \mathrm{p}=0.568)$, and the high level of severity $(\mathrm{b}=-1,735,612 ; \mathrm{CI}(95 \%)=-$ $3,482,347$ to 11,$123 ; \mathrm{p}=0.051)$. The INA-CBGs rate difference and $\mathrm{RS}$ real rates of labor cases decreased due to the classification of private hospitals $(b=281,021$; CI $(95 \%)=-73,054$ to 635,097; $\mathrm{p}=0,119)$, treatment class II $(\mathrm{b}=8,736$; CI $(95 \%)=-392,068$ to 409,$541 ; \mathrm{p}=0.966)$.

Conclusion: The difference in rates between INA-CBGs rates and hospital real rates in childbirth cases would increase if it serves treatment class III, type of cesarean delivery, care days which are longer, and moderate or severe severity. The difference in rates between INA-CBGs rates and hospital real rates in childbirth cases can decrease in services at private hospitals and serve treatment classes II.
\end{abstract}

Keywords: INA-CBGs rates, hospital real rates, labor costs.

\section{Correspondence:}

Baiq Holisatul Ismiana. Masters Program in Public Health, Universitas Sebelas Maret. Jl. Ir. Sutami No. 36 A, Surakarta 57126, Jawa Tengah, Indonesia. Email: baiqholis26@gmail.com. Mobile: +6287739031046.

\section{BACKGROUND}

Health is part of the state's economic and social development (WHO, 2010a). This fact requires that each country provide affordable and quality health care facilities for all levels of society (WHO, 2010b). On the other hand, not all countries have sufficient financial capacity to facilitate the health of their people for free. There are more than 1 billion people in the world who cannot access the health services they need, around 100 million people become poor 
and more than 150 million people experience financial difficulties due to out of pocket payments for the health services they use (WHO, 2010a).

Health insurance financing techniques are now increasingly being used by low to middle income countries as a means to guarantee health services for citizens and to avoid catastrophic health expenditures (Spaan et al., 2012).

Based on the Republic of Indonesia Health Profile in 2017, the decline in MMR in Indonesia occurred from 1991 to 2007 , from 390 to 228. In 2012, the MMR increased significantly to 359 maternal deaths per 100,000 live births. In 2015 AKI decreased to 305 maternal deaths per 100,000 live births (Ministry of Health, 2018).

Most of the causes of AKI can be prevented if access to labor to health facilities is more easily accessible and the handling of complications is more effective and efficient. Tiered health services in insurance financing schemes are expected to be one way to bring access to health facilities closer and speed up the handling of complications.

In Indonesia, one of the Government's efforts to guarantee the rights of its citizens to get health services is the compilation of the National Social Security System (SJSN) which is regulated in the Law of the Republic of Indonesia No. 40 of 2004. Social Security Administering Agency (BPJS) is a social security organizing body that organizes health insurance programs (Republic of Indonesia Law No.40 of 2004).

In accordance with Presidential Regulation Number 12 of 2013 concerning Health Insurance as amended by Presidential Regulation Number 111 of 2013, the pattern of payments to advanced health facilities is with INA-CBGs (Indonesia-Case Based Groups). INA-CBGs is a change in the nomenclature of INA-DRG (IndonesiaDiagnosis Related Group), a casemix system developed by the Government for prospective payment patterns for hospitals since 2006. (Permenkes RI No.76 of 2016).

In its implementation, payments through the INA-CBGs system often experience problems. The results of previous studies indicate that the INA-CBGs tariff rates do not match the real rates calculated from the unit cost of the type of health services provided. A study by Mardhatillah et al. (2018) examined the differences in INA-CBGs rates and hospital costs in hemodialysis patients showed that the INACBGs rates were lower than the real hospital rates. Several factors include the classification of hospitals, class of care, length of treatment, and severity of the alleged influence of large differences in health care costs.

Based on the background, it was interested to examine more about "Determinants of Differences in Real Rates and INA-CBGs in Labor Cases in Government and Private Hospitals in Mataram City, NTB".

\section{SUBJECTS AND METHOD \\ 1. Study Design \\ This study used an observational analytic design with a cross sectional approach. The location was at Kota Mataram hospital and Siti Hajar Mataram Islamic hospital, NTB. It was conducted in May 2019.}

\section{Population and Samples}

The population of this study was maternity patients in Mataram City Hospital and Siti Hajar Mataram Hospital in January - April 2019. The sample amounted to 200 samples. The sampling technique used was stratified random sampling.

\section{Study Variables}

The dependent variable was difference of real cost and INA-CBGs reimbursement. 
The independent variables were type of hospital, type of class treatment, type of birth delivery, length of stay, and severity disease.

\section{Operational Definition of Variables} Hospital classification was a type of hospital based on Indonesian Minister of Health Regulation No.56/Menkes/PER/I/ 2014. Hospital classification included public and privat hospitals. The data were collected by hospital record. The measurement scale was categorical scale.

Type of class treatment was the level of health care for patients in hospitals. The data were collected by hospital service registration. The measurement scale was categorical.

The type of labor was the technique of removing the fetus in term pregnancy, in this study it was limited to normal vaginal delivery and caesarean section. The instrument was the delivery room service registration. The measurement scale was categorical.

Length of stay was the number of days the patient is admitted to hospital. The instrument was claim data on Health Insurance Claims Installation (IKJK) Hospital. The measurement scale was continous.

The severity was the scale of case severity based on INA-CBGs coding, in accordance with Ministry of Health Regulation no.69 of 2013, namely: severity I (mild), severity II (moderate), and severity III (severe). The instrument was claim data on Health Insurance Claims Installation (IKJK) Hospital. The measurement scale categorical.

The INA-CBG rates for childbirth cases are the amount of money paid by the BPJS for each delivery case claimed by the hospital. The rate has been determined by the Government in accordance with the Republic of Indonesia Ministry of Health Regulation No. 52 of 2016. The instrument for the research of claim data for the Health Insurance Claims (IKJK) Hospital. The measurement scale was continous.

The real cost for childbirth cases was the amount of money the patient must pay to the hospital after obtaining obstetric services. The value rate has been determined by the Hospital. The instrument was claim data on Health Insurance Claims Installation (IKJK) Hospital. The measurement scale was a continuous scale.

INA-CBGs rate difference and real hospital rates for labor cases are the result of deductions from INA-CBGs rates and RS real rates in each delivery case. The instrument was claim data on Health Insurance Claims Installation (IKJK) Hospital. The measurement scale was continous.

\section{Data Analysis}

Univariate analysis was conducted to obtain an overview of the data on each study variable. Bivariate analysis was performed to analyze the relationship between independent and dependent variables. The mean difference of the two groups was tested using the T-test. Mean differences of more than two groups were tested by oneway ANOVA. The difference in the percentage of two or more groups was tested by chi-square. Multivariate analysis was conducted by a multiple linear regression.

\section{Research Ethics}

The ethics of this study included informed consent, anonymity, confidentiality, and ethical approval. Ethical permission was obtained from the hospital's Research Ethics Committee of Dr Moewardi hospital with number: 595 / IV / HREC / 2019.

\section{RESULTS}

\section{Univariate Analysis}

Based on Table 2, the number of caesarean (SC) deliveries was higher (57.5\%) compared to vaginal spontaneous labor (42.5\%). Most labor cases with mild seve- 
rity were 152 (76\%). In this study, samples were taken from government hospitals and private hospitals each by 50\%. The first class of care samples was $33 \%$, the second treatment class was $33 \%$, and treatment class IIII was $34 \%$.

\section{Bivariate Analysis}

Table 3 showed that there was a significant influence on the length of stay on the difference of INA-CBGs and real cost.
Table 4 shows that there was no influence on the classification of RS, treatment class, and severity of the difference in INACBGs rates and the real hospital hospital rates of labor cases significantly. There was a significant influence on the type of labor on the INA-CBGs tariff difference and the $\mathrm{RS}$ real rate of childbirth cases.

Table 1. Sample characteristics (continous data)

\begin{tabular}{llcrrr}
\hline Variable & N & Mean & SD & Min. & \multicolumn{1}{c}{ Max. } \\
\hline $\begin{array}{l}\text { INA-CBGs rate } \\
\text { (Rupiah) }\end{array}$ & 200 & $4,316,702$ & $2,067,409$ & $1,605,500$ & $7,423,300$ \\
$\begin{array}{l}\text { Hospital real rate } \\
\text { (Rupiah) }\end{array}$ & 200 & $6,109,185$ & $2,995,842$ & $1,609,400$ & $13,919,812$ \\
$\begin{array}{l}\text { Difference rate } \\
\text { (Rupiah) }\end{array}$ & 200 & $-1,792,483$ & $1,408,319$ & $-8,330,496$ & 565,500 \\
$\begin{array}{l}\text { Duration of treatment } \\
\text { (hari) }\end{array}$ & 200 & 2.82 & 0.93 & & 1 \\
\hline
\end{tabular}

Table 2. Sample characteristics (categorical data)

\begin{tabular}{llcc}
\hline Independent Variables & \multicolumn{1}{c}{ Category } & N & \% \\
\hline Hospital classification & Public hospital & 100 & 50.0 \\
& Private hospital & 100 & 50.0 \\
Type of class treatment & Class I & 66 & 33.0 \\
& Class II & 66 & 33.0 \\
& Class III & 68 & 34.0 \\
Type of birth delivery & Vaginal birth & 85 & 42.5 \\
& Sectio cesarean & 115 & 57.5 \\
Level of severity disease & Mild & 152 & 76.0 \\
& Moderate & 46 & 23.0 \\
& Severe & 2 & 1.0 \\
\hline
\end{tabular}

Table 3. Results of bivariate analysis (continuous data)

\begin{tabular}{lcccccc}
\hline Variable & n & Mean & SD & Min. & Max. & p \\
\hline length of stay (day) & 200 & 2.82 & 0.93 & 1 & 6 & $<0.001$ \\
\hline
\end{tabular}

Table 4. Bivariate analysis results (categorical data)

\begin{tabular}{llcccc}
\hline Variabel & Category & N & Mean & SD & p \\
\hline Hospital & Govermental hospital & 100 & $-1,921,054$ & $1,600,582$ & 0.901 \\
classification & Private hospital & 100 & $-1,663,912$ & $1,179,620$ & \\
Treatment level & I & 66 & $-1,785,964$ & $1,367,308$ & 0.217 \\
& II & 66 & $-1,579,589$ & $1,270,668$ & \\
Type of labor & III & 68 & $-2,005,442$ & $1,555,647$ & \\
& Vaginal spontaneous & 85 & $-921,557$ & $1,202,376$ & $<0.001$ \\
length of stay & Light & 115 & $-2,436,211$ & $1,188,844$ & \\
& Medium & 46 & $-1,810,292$ & $1,263,883$ & 0.214 \\
& Heavy & $-1,662,885$ & $1,809,596$ & \\
\hline
\end{tabular}




\section{Multivariate Analysis}

Table 5 shows the classification of hospitals influencing the difference in INA-CBGs rates and $\mathrm{RS}$ real rates. Public hospitals would suffer more losses of $\mathrm{Rp} 281,021$ compared to private hospitals in each delivery case, although statistically not significant $(b=281,021 ; 95 \% \mathrm{CI}=-73,054$ to 635,097; $\mathrm{p}=0.119$ ).

Class II care was more profitable $\mathrm{Rp}$ 8,736 compared to class I care even though it was not statistically significant $(b=8,736$; $95 \% \mathrm{CI}=-392,068$ to 409,$541 ; \mathrm{p}=0.966)$. Whereas, the III care class was more loss Rp 390,725 compared to the first care class $(b=-390,725 ; 95 \% \mathrm{CI}=-790,082$ to 8,631 ; $\mathrm{p}=0.055)$.

Types of labor (section caesarea) was negatively affected the difference in real cost and INA-CBGs reimbursement. The hospital would experience a greater loss of Rp 1,429,648 in each case of SC labor compared to vaginal vaginal delivery $(b=-$ $1,429,648 ; 95 \% \mathrm{CI}=-1,811,275$ to 1,048,022; p <0.001).

Length of stay had a negative effect on the difference in INA-CBGs rates and RS real rates. Each increase in the number of days of care per day would add to the hospital losses of $R p$ 211,912 (b= -211,912; $95 \% \mathrm{CI}=-427,786$ to 3,$960 ; \mathrm{p}=0.054)$.

\section{Table 5. Multiple linear regression analysis}

\begin{tabular}{|c|c|c|c|c|}
\hline \multirow{2}{*}{ Independent Variables } & \multirow{2}{*}{ b } & \multicolumn{2}{|c|}{ CI 95\% } & \multirow[b]{2}{*}{$\mathbf{p}$} \\
\hline & & Lower Limit & Upper Limit & \\
\hline Private hospital & 281,021 & $-73,054$ & 635,097 & 0.119 \\
\hline Class II & 8,736 & $-392,068$ & 409,541 & 0.966 \\
\hline Class III & $-390,725$ & $-790,082$ & 8,631 & 0.055 \\
\hline SC labor type & $-1,429,648$ & $-1,811,275$ & $-1,048,022$ & $<0.001$ \\
\hline Duration of treatment (day) & $-211,912$ & $-427,786$ & 3,960 & 0.054 \\
\hline Level of severity: moderate & $-114,028$ & $-507,057$ & 279,000 & 0.568 \\
\hline Level of severity: severe & $-1,735,612$ & $-3,482,347$ & 11,123 & 0.051 \\
\hline Constanta & 808,821 & $-13,962$ & $1,631,606$ & 0.054 \\
\hline \multicolumn{5}{|l|}{$\mathrm{N}$ observation $=200$} \\
\hline \multicolumn{5}{|l|}{ Adj R-squared= 0.35} \\
\hline $\mathrm{p}<0.001$ & & & & \\
\hline
\end{tabular}

Moderate severity was more than $\mathrm{Rp}$ 114,028 compared to mild levels but was not statistically significant for the hospital $(b=-114,028 ; 95 \% \quad C I=-507,057$ to 279,000; $p=0.568)$. Meanwhile, severity disease is more than $\mathrm{Rp} 1,735,612$ compared to the mild severity $(b=-1,735,612$; $95 \% \mathrm{CI}=-3,482,347$ to 11,$123 ; \mathrm{p}=0.051$ ).

\section{DISCUSSION}

\section{Hospital rates are compared to the rates of INA-CBGs}

This study shows that INA-CBGs rates in labor cases were lower than the real hospital rates. The results of this study were in line with the study of Mardhatillah et al. (2018) which shows that there was a difference between INA-CBGs tariff claims and $\mathrm{RS}$ real rates in patients with chronic renal failure. INA-CBGs rates $($ mean $=\mathrm{Rp}$ 6,120,000; $\mathrm{SD}=\mathrm{Rp}$ 2,330,000) hemodialysis was lower than real cost (mean $=\mathrm{Rp}$ 7,070,000; $\mathrm{SD}=\mathrm{Rp}$ 4,650,000).

The concept of costs and rate was a fundamental thing in providing health services. Costs are a number of lost values to obtain or produce certain commodities, while the rate was the value of a service determined by the size of a certain amount of money (Trisnantoro, 2004). The calcula- 
tion of hospital rates was usually adjusted to the mission of each hospital. Whereas BPJS Kesehatan was as the executor of the National Health Insurance (JKN) applies the INA-CBGs system as a guideline for calculating health service tariffs.

\section{Hospital advantages and disadvan- tages related to INA-CBGs claims rate}

The results of data analysis showed that the INA-CBG rates for childbirth cases were lower than the hospital's real rates, so hospitals suffered losses. This result is in line with the study conducted by Yuniarti et al. (2015) which shows that the rates of INA-CBGs are lower than the real rates of hospital in cases of patients with diabetes mellitus (the average rate of INA-CBGs for type 1 DM disease per outpatient episode is Rp.247,200, and hospital outpatient rates are $\mathrm{Rp} 563,817$ + Rp 255,080. The average rate of INA-CBGs for type $2 \mathrm{DM}$ disease per outpatient episode was $\mathrm{Rp} 185,376$, and hospital outpatient rates were Rp 374,197 + Rp 323,237).

Hospital rates are an aspect that is very much considered by private hospitals as well as by government-owned hospitals. For some government hospitals, rates were indeed determined based on Minister of Health Decree or Regional Government. One of them is Kota Mataram hospital, determining the rate using the Mayor of Mataram Regulation Number 6 of 2017 concerning service rates at the Mataram City General Hospital. This shows the existence of strict government control as the owner of the hospital as a firm or business actor. However, it was realized that government rate generally have low cost recovery. While the Private Hospital, in this study, Siti Hajar Islamic hospital Kota Mataram set hospital rates based on competitor analysis and demand so that the prices given are increasingly competitive.

\section{Effect of hospital classification on the difference in INA-CBGs rates and hospital rates}

The results of multivariate analysis showed that the classification of hospital had an effect on the difference in INA-CBGs rates and hospital real rates even though it was not statistically significant. Government hospitals suffered more losses compared to private hospitals in each delivery case. This study is in line with Rahayuningrum et al. (2017) which shows the existence of a negative relationship between hospital rates and types (classification) of hospital in hospitalized patients. The rate of private hospitals was lower than government hospitals $(b=-5.66 x$ Rp. 1,000,000; $p=0.078)$.

The cost of private hospitals was lower than the cost of government hospitals because of the basis of decision making in the preparation of different tariffs. Private hospitals were more competitive in determining rates so they can compete with the market. While the Government Hospital, the rate determination is based on the respective regional regulations.

In addition, the internal efficiency of private hospitals was often better than government hospitals. Private hospitals can be more efficient because they work together in networks, so they can support each other in various aspects of management (Trisnantoro, 2004).

\section{The effect of treatment class with INA-CBGs rate difference on hospital rates}

The results of the multivariate analysis showed that the treatment class affected the difference in INA-CBGs rates and hospital rates. Class II care is more profitable than class I care even though it is not statistically significant. And III care class is more disadvantaged compared to class I treatment and statistically close to significant. 
A study by Muslimah et al. (2017) who examined the comparison of the real costs and rates of INA-CBGs of ischemic stroke in Bethesda Hospital, Yogyakarta, showing the results that there were significant differences between the real costs of the hospital and the INA-CBGs rates in the treatment class I.

The National Health Insurance concept expects cross subsidies from higher care classes for lower care classes. This can ease the financing of hospital services for the weak economic community. With this cross subsidy concept, VIP or class I rates must be above the unit cost so that the surplus can be used to overcome losses in class III wards (Trisnantoro, 2004).

\section{The effect of type of labor on the difference in INA-CBGs rates and hospital rates}

The results of this study indicated that the type of labor had a negative effect on the difference in INA-CBGs rates and hospital real rates and was statistically significant. Both government hospitals and private hospitals would experience greater losses in each case of sectio caesarean births than vaginal vaginal delivery cases.

This finding is in line with the study by Entringer et al. (2019) which analyzed the effectiveness of the cost of vaginal delivery and elective cesarean section without clinical indications. The costs of vaginal vaginal delivery, planned sectional caesarean section and daily hospital costs in care for three maternity hospitals were identified. The average cost of a vaginal delivery procedure was R \$ 808.16 and ranges from R \$ 585.74 to R \$ 916.14 among hospitals. The average cost of planned Cesarean section is $\mathrm{R} \$ 1,113.70$, starting from $\mathrm{R} \$$ 652.69 to $R \$ 1,516.02$. In the past few years, there had been a tendency to increase labor by caesarean section (Entringer et al., 2019).
Entringer et al. (2018) stated that normal labor is more cost-effective than caesarean delivery for riskless primiparous patients. Planned caesarean delivery without clinical indications has a negative impact on maternal and newborn health outcomes, which leads to increased length of stay, increased hysterectomy, blood transfusion, ICU hospitalization and even higher neonatal mortality.

\section{The effect of the treatment duration on the difference in INA- CBGs rates and hospital rates}

The results of multivariate analysis show that the length of treatment had a negative influence on the difference in INA-CBGs rates and real hospital rates and was statistically close to significant. Each increase in the number of care days would increase the difference in INA-CBGs rates and RS real rates. In line with the study conducted by Rahayuningrum et al. (2017) which shows the results there is a relationship between hospital rates and length of stay $(b=0.27 \mathrm{x}$ $\mathrm{Rp}$ 1,000,000; $\mathrm{p}=0.005$ ) inpatients of JKN participants in hospitals in Surakarta.

Average Length of Stay (ALOS) in hospitals is often used as an indicator of efficiency. If all other factors are considered the same, shorter hospitalization periods will reduce the cost of care and change care from hospitalization to cheaper post-acute care. However, a short treatment day can also cause adverse effects on the outcome of the service, or reduce patient comfort and recovery (OECD, 2013).

In 2011, ALOS for normal births averaged three days, ranging from less than two days in Mexico, Turkey, England, Canada, New Zealand and Iceland, to more than five days in Hungary and the Slovak Republic (OECD, 2013) .

Most countries try to reduce ALOS while maintaining or improving the quality of care. A number of diverse policy options 
at the clinical, service and system level could be used to achieve this goal including promoting the taking of less invasive surgical procedures, changing hospital payment methods, expanding early return programs that allow patients to return to their homes to receive follow-up care (Borghans et al., 2012).

\section{The effect between severity and the difference in INA-CBGs rates and hospital rates}

The results of this study indicated that moderate severity was more loss compared to mild severity even though it was not statistically significant. The severity of the loss was more than the mild severity and was statistically significant.

A study conducted by Howland et al. (2018) which examined the association of estimated labor costs at hospitals with the severity of mothers in New York in 20082012 indicates that the cost of delivery to mothers with severe maternal morbidity delivery was $\$ 14,442$ (95\% CI \$ 14,128 14,756 ), compared to $\$ 7,289$ (95\% CI $\$$ 7,276-7,302) in births with mild severity.

A study conducted by Herrmann et al. (2010) who examined the relationship between disease severity and the cost of treating patients with Alzheimer's in Canada also showed that the total costs associated with Alzheimer's disease (AD) were significantly higher in $\mathrm{AD}$ with greater severity. The average total cost for treating patients with very mild AD (Global Deterioration Scale $=2$ ) is $\$ 367$ per month, compared to $\$ 4063$ per month for patients with severe or very severe AD (Global Deterioration Scale $=6$ ).

Severe severity tends to encourage a more complex health care system that requires greater costs. Patients with more severe severity would need longer treatment and more types of health services.

\section{AUTHORS CONTRIBUTION}

Baiq Holisatul Ismiana contributed as the main author who played roles in determining the ideas and conducting the study. Didik Tamtomo and Endang Sutisna Sulaeman contributed to the improvement and method of writing the report.

\section{FUNDING AND SPONSORSHIP}

This study was self-funded.

\section{CONFLICT OF INTEREST}

There was no conflict of interest in this study.

\section{ACKNOWLEDGEMENT}

The author thanked the Director of Mataram City General Hospital and Director of Siti Hajar Mataram Islamic hospital and all hospital staff who had contributed and helped with this study.

\section{REFERENCE}

$\overline{\text { Borghans I, Lagoe RJ, Kool T, Westert GP }}$ (2012). Fifty ways to reduce length of stay: An inventory of how hospital staff would reduce the length of stay in their hospital. Health Policy. 104(3): 222-33. doi: 10.1016/j.healthpol.2011.12.010.

Entringer AP, Pinto M, Gomes MA (2018) Cost-effectiveness analysis of natural birth and elective $\mathrm{C}$-section in supplemental health. Rev Saude Publica. 52: 91. doi: 10.11606/S1518-8787.2018052000373.

Entringer AP, Pinto M, Gomes MA (2019). Costs analysis of hospital care for vaginal delivery and elective caesarean section for usual risk pregnant women in the Brazilian Unified National Health System. Ciênc. Saúdecoletiva. 24(4) Rio de Janeiro. doi: 10.1590/141381232018244.06962017 
Herrmann N, Tam DY, Balshaw R, Sambrook R, Lesnikova N, Lanctôt KL (2010). The relation between disease severity and cost of caring for patients with Alzheimer disease in Canada. Can J Psychiatry. 55(12): 768-75. doi: 10.1177/070674371005501204

Howland RE, Angley M, Won SH, Wilcox W, Searing H, Tsao TY (2018). Estimating the hospital delivery costs associated with severe maternal morbidity in New York City, 2008-2012. Obstet Gynecol. 131(2):242-252. doi: 10.1097/AOG.000000000000-2432.

Kemenkes RI (2018). Profil Kesehatan Indonesia Tahun 2017 (Indonesia Health Profile 2017). Jakarta: Kementerian Kesehatan RI

Mardhatillah, Tamtomo DG, Murti B (2017). Factors influencing the difference between Indonesian Case-Based Group reimbursement and medical cost for patients with chronic renal disease cases in Kasih Ibu Hospital, Surakarta. Journal of Health Policy and Management. 2(2): 117-127. doi: 10.26911/thejhpm.2017.02.02.03

Muslimah, Andayani TM, Pinzon R, Endarti $D$ (2017). Comparison of Real Costs against the Price of INA-CBG's Ischemic Stroke in Bethesda Hospital. Jurnal Manajemen dan Pelayanan Farmasi. 7(2). doi: 10.22146/jmpf.30289

OECD (2013). Average length of stay in hospitals, in Health at a Glance 2013: OECD Indicators, OECD Publishing, Paris. doi: 10.1787/health_glance2013-36-en

Ministry of Health Regulation of RI No. 76 in 2016 Pedoman Indonesian Case Base Groups dalam pelaksanaan jaminan kesehatan nasional.
Rahayuningrum IO, Tamtomo DG, Murti B (2017). Comparison between hospital inpatient cost and INA-CBGs reimbursement of Inpatient Care in the National Health Insurance Scheme in Solo, Karanganyar, Boyolali District Central Java. Journal of Health Policy and Management 1(2): 102-112. doi: 10.26911/theicph.2017.138

Spaan E, Mathijssen J, Tromp N, McBain F, Haveb AT, Baltussen R (2012). The impact of health insurance in Africa and Asia: a systematic review. Bull World Health Organ, 90:685-692A. doi: 10.2471/BLT.12.102301

Trisnantoro L (2004). Memahami Ilmu Ekonomi Dalam Manajemen Rumah Sakit (Understanding Economics in Hospital Management). Yogyakarta; Gadjah Mada University Press

UU Republik Indonesia No. 40 Tahun 2004 tentang Sistem Jaminan Sosial Nasional (Republic of Indonesia Law No.40 of 2004 concerning the National Social Security System).

WHO (2010a). Health systems financing: The path to universal coverage; World Health Report 2010. Retrieved from http://www.who.int/whr/2010/en/

WHO (2010b). WHO urges all countries to strengthen health financing so more people can use services. Retrieved from http://www.who.int/mediacentre/news/releases/2010/whr_201011 22/en/

Yuniarti E, Amalia, Handayani TM (2015). Analisis biaya terapi penyakit diabetes melitus pasien jaminan kesehatan nasional di RS PKU Muhammadiyah Yogyakarta: Perbandingan terhadap tarif INA CBGs. Jurnal Kebijakan Kesehatan Indonesia. 4(3): 97-103. doi: 10.22146/jkki.v4i3.36108. 